Original Research Article

\title{
Effects of access to livelihood capitals on adoption of European Union (EU) approved pesticides among cocoa-producing households in Osun State, Nigeria
}

\author{
Ayodeji Damilola Kehinde*, Akeem Abiade Tijani \\ Department of Agricultural Economics, Faculty of Agriculture, Obafemi Awolowo University, Ile Ife, Osun State, Nigeria
}

Correspondence to:

A. D. Kehinde, Department of Agricultural Economics, Faculty of Agriculture, Obafemi Awolowo University, Ile Ife, Osun State, Nigeria; kehindeayodeji8@gmail.com

\begin{abstract}
Cocoa-producing households' access to livelihood capitals would help them to adopt EU approved pesticides successfully. However, no empirical studies have addressed these issues. This study therefore investigated the effects of access to livelihood capitals on adoption of EU approved pesticides among cocoa-producing households. A multi-stage sampling procedure was employed to select 120 cocoa-producing households for the study. The obtained data were analysed using descriptive statistics, multivariate probit regression and double hurdle regression model. The majority of cocoa-producing households $(92 \%)$ have access to natural capital, followed by physical capital (67.5\%), social capital (62.5\%), financial capital (58\%), whereas only a few (50.8\%) have access to human capital. Multivariate probit estimates showed that age $(p<0.05)$, gender $(p<0.05)$, farm size $(p<0.05)$, years of education $(p<0.01)$, farming experience $(p<0.01)$, household size $(p<0.01)$ and membership in cooperative society $(p<0.01)$ significantly influenced cocoa-producing households' access to livelihood capitals. The majority of cocoa-producing households (81\%) adopt approved pesticides. The first hurdle estimates showed that gender $(p<0.01)$, education $(p<0.05)$, membership in a cooperative society $(p<0.05)$ and access to some livelihood capitals such as human $(p<0.01)$, physical $(p<0.05)$ and financial $(p<0.01)$ capitals significantly influence the probability of adoption of EU approved pesticides. In the second hurdle, gender $(p<0.1)$, farm size $(p<0.01)$, household size $(p<0.01)$, membership in a cooperative society $(p<0.01)$ and access to some livelihood capitals such as human $(p<0.05)$, physical $(p<0.01)$ and social $(p<0.01)$ capitals are significant in determining the intensity of adopting EU approved pesticides. The study concluded that access to livelihood capitals has potentials of accelerating adoption of EU approved pesticides. Other factors include gender, education, farm size and membership in a cooperative society. Therefore, this study suggests that government policy on uptake of EU approved pesticides should pay more attention on cocoa-producing households' access to all these factors. Most importantly, policy package to encourage access to livelihood capitals must be strongly advocated.
\end{abstract}

Keywords: Theobroma cacao L.; natural; physical; social; financial; human; capitals; age; gender; farm size; education; household size; cooperative society

\section{INTRODUCTION}

Cocoa (Theobroma cacao L.) is a perennial crop mainly cultivated in West Africa with over $70 \%$ of the global cocoa production (UNDP, 2010; Afrane and Ntiamoah, 2011). Nigeria is one of the principal producers of cocoa in West Africa (UNECA, 2013). In Nigeria, cocoa plays important economic roles in terms of foreign exchange earnings, revenue generation to cocoa producing states, Osun State inclusive, provision of employment to people, and income generation to many farming

(c) AUTHORS 2021.

This work is licensed under the Creative Commons Attribution-NonCommercial-NoDerivs 4.0 License (https://creativecommons.org/licenses/by-nc-nd/4.0/) 
households (Verter and Becvarova, 2014). Despite these significant economic roles, cocoa production has been crippled by numerous factors, incidence of pests and disease inclusive (Uwagboe et al., 2011) and this led to the use of pesticides.

Pesticides are used to control cocoa pests in production, storage and processing (Bateman, 2010). They provide useful control solutions, but must be approved for use on the basis of good and appropriate application practices. Studies (e.g., Williamson, 2003; Adefila, 2013) have noted that indiscriminate application of pesticides could lead to residue in cocoa beans which can make them unsafe for human consumption. About 3 million people suffer from various severe illnesses such as impaired thyroid function, low sperm count, testicular cancer, birth defects, endocrine disruptions, dermatitis, immunotoxicity, neurobehavioural disorders, headaches, body aches, skin or eye irritation, respiratory problems. About 20,000 deaths are recorded annually as a result of pesticide poisoning (Cocco et al., 2013; Gill and Garg, 2014). Consequently, European Union became conscious of this and in 2008, enacted a regulation on pesticide maximum residue limits (MRLs) allowed on cocoa beans and its derivatives.

In line with the EU regulation, the Federal Government of Nigeria reviewed the pesticides used on cocoa farms (Mokwunye et al., 2012). All the cocoa pesticides underwent screening and some of the previously used pesticides were banned (ICCO, 2008). Nevertheless, pesticides such as Actara 25WG, Esiom 150SL, Funfurun-OH, champ DP, Ridomilgold 66WP, ultimax plus, Kocide 2000, Touch down round, Round up Clear weed, and Phostoxin were approved for use on cocoa farms. Unfortunately, some farmers are yet to comply with the usage of approved cocoa pesticides only, and still use the banned ones on their farms. Abdullahi (2008) and Mokwunye (2014) noted that the adoption of the EU approved pesticides has been generally low. There have been many challenges coming up concerning farmers' adoption of EU approved pesticides. One of these challenges is that most cocoa farmers barely have access to livelihood capitals which has made it impossible for them to meet up with the EU requirement of minimum residues (Adefila, 2013). Livelihood capitals refer to different categories of the vital resource bases of the households. The categories are human, natural, financial, physical and social capitals.

Financial capitals cover income, savings and other liquid assets of the households. Human capitals are skills, knowledge, education, ability to work and experience possessed by members of the households.
Physical capitals are basic household's asset, facilities, housing, and farm tools. Natural capitals are the number and size of farms possessed by the household. Social capitals are relationships of trust and households' membership of social groups. Cocoa-producing households' access to these livelihood capitals could form resource bases to hasten up adoption of EU approved pesticides successfully especially in Nigeria where cocoa-producing household currently lack access to these capitals. However, no empirical studies have addressed the issues of livelihood capitals and adoption of EU approved pesticides to the best knowledge of the authors. Studies (Fang et al., 2011; 2012; Diniz et al., 2013) on livelihood capitals are largely tailored to issues like poverty, food security and choice of livelihood options or strategies. Nevertheless, this study hypothesises a positive influence of access to livelihood capitals on the probability and intensity of adopting EU approved pesticides among cocoa-producing households.

Thus, an important goal of this study was to investigate in detail the effect of access to livelihood capitals on the adoption of EU approved pesticides among cocoa-producing households with appropriate econometric model, double hurdle developed by Cragg (1971) to provide a clearer picture of the effect of access to livelihood capitals on the two hurdles of adoption faced by the households. Specifically, the study identifies the livelihood capitals available to cocoa-producing households; determines the factors affecting the access of cocoa-producing households to livelihood capitals; determines the cocoa-producing households' probability and intensity of adopting of the EU approved pesticides; and determines the effects of access to livelihood capitals on the probability and intensity of adopting them among cocoa-producing households.

\section{MATERIALS AND METHODS}

\section{The study area}

The study was carried out in Osun State, located in the south-western part of Nigeria having coordinates $7^{\circ} 30^{\prime} \mathrm{N} 4^{\circ} 30^{\prime} \mathrm{E} / 7.500^{\circ} \mathrm{N} 4.500^{\circ} \mathrm{E}$. Osun State is generally referred to as "state of the virtuous", and was created on 27 $7^{\text {th }}$ August 1991. The State is situated in the tropical rain forest zone with an annual rainfall of $1570 \mathrm{~mm}$ and temperature between $25^{\circ} \mathrm{C}$ and $27.5^{\circ} \mathrm{C}$ and it covers a land area of 14,875 square meters. The population of the State in 1991 was 2,158, 143, in 2006 was 3,416,959 (NPC, 2007) and 2017 was 4,705,589 (NPC, 2017). It is bounded in the north by Kwara State in the east partly 
by Ekiti State and partly by Ondo State, in the South by Ogun State and in the west by Oyo State (see Figure 1). Food crops grown in the State include maize (Zea mays), yam (Dioscorea spp.), cassava (Manihot spp.), rice (Oryza sativa) and vegetables. The cash crops include cocoa (Theobroma cacao), kolanut (Cola nitida) and oil palm (Elaeis guinensis). These crops are usually mixed or intercropped. Cocoa is the main export crop grown in this State and it is second to Ondo in terms of cocoa production (Popoola et al., 2015).

\section{Sampling procedure and sample size}

Multistage sampling procedure was used to select respondents for the study. The first stage was a purposive selection of two Local Government Areas (LGAs) which are Ife North and Ife Central based on the predominance of cocoa farmers in the LGAs. The LGAs are among major producers of cocoa beans and contribute greatly to Osun State's total cocoa output (Amao et al., 2015). The population of the selected LGAs is 320,948 (NPC, 2017). The second stage involved a simple random selection of three communities from each LGA. In Ife North LGA, Agodo, Majarayomi and Yakoyo villages were selected while Fasanu, Jabata and Olooyo villages were selected in Ife East LGA. The third and final stage involved a simple random selection of twenty cocoa-producing households in each of the selected communities. A total number of 60 cocoa-producing households were selected in each LGA. This makes a total number of 120 cocoa-producing households selected for the study.

\section{Analytical techniques}

Firstly, descriptive statistics such as mean and percentage were used to identify the livelihood capitals available to cocoa-producing households and profile cocoa-producing households' probability and intensity of adopting EU approved pesticides. The obtained data were further analysed with the aid of multivariate probit regression, and the double hurdle model.

\section{Multivariate probit regression model}

A multivariate probit regression model was used to determine the factors that affect cocoa-producing households' access to livelihood capitals. In this study, five categories of livelihood capitals were considered. They are physical capital, financial capital, natural capital, social capital and human capital. In this model, the dependent variable includes the five categories of livelihood capitals under study while the socio-economic characteristics of cocoa-producing households are the independent variables. This model was employed because it accommodates more than two categories in the dependent variable of probability analysis and allows complementary or substitutability among the categories of the dependent variables.

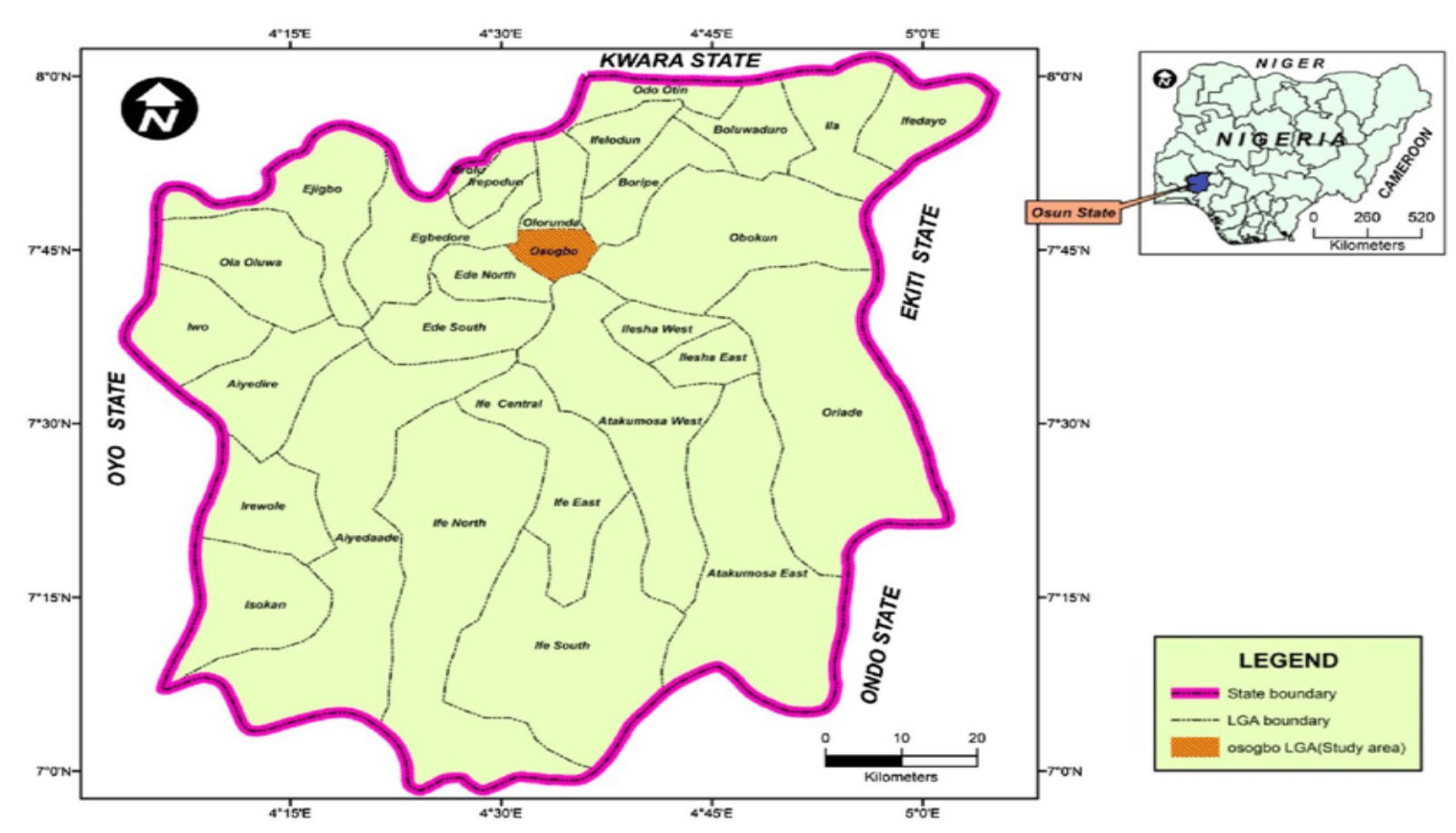

Figure 1. Map of Osun State 
The estimated model is specified explicitly as follows:

$\mathrm{Y}_{i}=\beta_{0}+\beta_{1}$ GENHHED $+\beta_{2}$ AGEHHED $+\beta_{3}$ FFEDU +

$+\beta_{4}$ FAMSIZE $+\beta_{5}$ FAMEXP $+\beta_{6}$ HHSIZE +

$+\beta_{7}$ MEMBAS $+\beta_{8}$ INCOMLEV $+e_{i}$

Where:

Yi is a single dependent variable with five categories ( $1=$ access to human Capital; $2=$ access to physical Capital; $3=$ access to natural Capital; $4=$ access to financial Capital and $5=$ access to social Capital).

The categories of livelihood capitals in the dependent variables are measured as follows:

Access to human capital is whether cocoa-producing households make use of skilled labour on cocoa farm or not $(\mathrm{No}=0$; Yes $=1)$; Access to physical capital is whether cocoa-producing households have physical assets like houses, cars among others (No $=0$; Yes $=1$ ); Access to natural capital is whether cocoa-producing households own a cocoa farm of their own either through purchases or inheritance ( $\mathrm{No}=0$; Yes $=1)$; Access to financial capital is whether cocoa-producing households have access to cash either through savings or loan (No=0; Yes $=1$ ); Access to social capital is whether cocoa-producing households participate in social group formation like friends and families, religious group, village associations among others to determine the social collateral of the households $(\mathrm{No}=0$; Yes $=1)$. The definitions of independent variables are: GENHHED is gender of household head $(0=$ female, $1=$ male), AGEHHED is age of the household (years), FFEDU is number of years of formal education (years), FAMSIZE is farm size (ha), FAMEXP is year of farming experience (years), HHSIZE is farm household size (\#), MEMBASS is membership of farmers' association (dummy variable $0=$ non-member, $l=$ member), INCOMLEV is income level (Naira) and $e_{i}$ is random error term. These explanatory variables are expected to influence the farmer's access to livelihood capitals.

\section{Double-Hurdle regression model}

This study employed the double-hurdle regression model to determine the effects of access to livelihood capitals on the adoption and intensity of use of the EU approved pesticides among cocoa-producing households. In this study, two hurdles of adoption are measured; specifically, the probability of adoption and intensity of adoption. The probability of adoption measures the decision of farmers to adopt a technology. In a different way, the intensity of adoption measures the extent of use of the adopted technology (Bonabana-Wabbi 2002). According to Rogers (2003), probability and intensity of adoption are affected by separate set of factors that can either hinder or support adoption of a given technology. In this regard, adoption and intensity were treated separately in this study. This suggests that farmers carry out decisions on EU approved pesticides' adoption and intensity independently.

In order for Nigeria to produce acceptable cocoa beans to meeting European Union Regulations

Table 1. Pesticides currently approved for use on cocoa farms in Nigeria

\begin{tabular}{|c|c|c|c|c|}
\hline $\mathbf{S} / \mathbf{N}$ & Trade Name & Active Ingredient & Commercial form & Pests \\
\hline \multicolumn{5}{|c|}{ Insecticides } \\
\hline 1 & Esiom 150 SL & Acetamiprid & Soluble liquid & Mirid \\
\hline 2 & Actara25WG & Thiamethoxan & Wettable granule & Mirid \\
\hline 3 & Proteus 170 O-TEQ & Deltamethrin 20g/L & Oil Dispersion & Mirid \\
\hline \multicolumn{5}{|c|}{ Fungicide } \\
\hline 4 & Funguran-OH & Copper hydroxide & Wettable powder & Black pod \\
\hline 5 & Champ DP & Copper hydroxide & Dustable powder & Black pod \\
\hline 6 & Ridomil gold 66WP & $\begin{array}{l}\text { Cuprous Oxide } \\
+ \text { metalaxyl-M }\end{array}$ & Wettable powder & Black pod \\
\hline 7 & Nordox 75WP & Cuprous Oxide & Wettable powder & Black pod \\
\hline 8 & Kocide 101 & Cuprous Oxide & Wettable powder & Black pod \\
\hline 9 & Ultimax plus & Cuprous Oxide & Wettable powder & Black pod \\
\hline \multicolumn{5}{|c|}{ Herbicides } \\
\hline 10 & Touch down & Glyphosate & Soluble concentrate & Weed \\
\hline 11 & Round up & Glyphosate & Soluble concentrate & Weed \\
\hline 12 & Clear weed & Glyphosate & Soluble concentrate & Weed \\
\hline \multicolumn{5}{|c|}{ Fumigants } \\
\hline 13 & Phostoxin & Aluminum Phosphides & Tabletized or Pelletised & Storage pests \\
\hline
\end{tabular}

Source: Cocoa Research Institute of Nigeria, 2015. 
on Maximum Residue limits (MRLs), the federal government has currently approved a list of pesticides for use on cocoa farms in Nigeria. These pesticides are shown in Table 1. Since the approved pesticides are mutually exclusive, an adopter in this study is defined as a farmer who invests in any of the approved pesticides.

In the first hurdle, the study adopted the probit regression model to determine the effect of access to livelihood capitals on probability of adopting EU approved pesticides among cocoa-producing households. The dependent variable is decision to adopt EU approved pesticides and the independent variables are multidisciplinary explanatory variables including livelihood capitals postulated to influence decision to adopt EU approved pesticides.

The estimated model is implicitly expressed as follows:

$\mathrm{Y}_{i}=\beta_{0}+\beta_{1} \mathrm{X}_{1}+\beta_{2} \mathrm{X}_{2}+\beta_{3} \mathrm{X}_{3}+\beta_{4} \mathrm{X}_{4}+\beta_{5} \mathrm{X}_{5} \ldots \beta_{15} \mathrm{X}_{15}$

$\mathrm{Y}_{\mathrm{i}}=$ decision to adopt ( 1 = adopt, $0=$ otherwise $)$

In second hurdle, a truncated regression model was used to determine the effects of access to livelihood capitals on the adoption intensity of the EU approved pesticides among cocoa-producing households. The dependent variable is the quantity of approved EU pesticides used on their respective cocoa farms per hectare and the independent variables are multidisciplinary explanatory variables including livelihood capitals postulated to influence intensity of use of EU approved pesticides.

The estimated model is implicitly expressed as follows:

$\mathrm{Y}_{i}=\beta_{0}+\beta_{1} \mathrm{X}_{1}+\beta_{2} \mathrm{X}_{2}+\beta_{3} \mathrm{X}_{3}+\beta_{4} \mathrm{X}_{4}+\beta_{5} \mathrm{X}_{5} \ldots \beta_{15} \mathrm{X}_{15}$

$\mathrm{Y}_{\mathrm{i}}=$ Quantity of approved EU pesticides used per hectare (litres).

Where:

The explanatory variables are:

$\mathrm{X}_{1}=$ Gender of the household head (Male $=1$, Female $=0$ ); $X_{2}=$ Age of household head (in years); $\mathrm{X}_{3}=$ Marital status of household head (Married = 1; Otherwise $=0$ ); $\mathrm{X}_{4}=$ Education of household head (years spent in formal education); $X_{5}=$ Farm size (hectares); $\mathrm{X}_{6}=$ Farming experience of household head (Years); $\mathrm{X}_{7}=$ Household size (Actual number of people in the household); $X_{8}=$ Membership in association (Member $=1$; Otherwise $=0$ ); $\mathrm{X}_{9}=$ Level of income (Naira) ; $\mathrm{X}_{10}=$ Access to extension service (access $=1$, no access $=0$ ); $X_{11}=$ Access to Human capital (access $=1$, no access $=0$ ); $X_{12}=$ Access to Physical capital (access $=1$, no access $=0$ ); $X_{13}=$ Access to Natural capital (access $=1$, no access $=0) ; X_{14}=$ Access to Financial capital (access $=1$, no access $=0$ ); $X_{15}=$ Access to Social capital (access $=1$, no access $=0$ ).

\section{RESULTS AND DISCUSSION}

\section{Socio-economic characteristics of cocoa-producing households}

The socio-economic characteristics of cocoa-producing households are presented in Table 2. Majority (94.2\%) of the cocoa-producing household heads are male. This result suggests that male-headed households dominate cocoa production in Osun State. A plausible reason could be that cocoa production requires physical strength and more labour. This study agrees with Mustapha et al. (2012) and Adeyemo et al. (2020). The mean age of the respondents is 58.7 years, i.e. the farmers are relatively old. This could be attributed to the fact that older people generally stay in the villages and relatively younger people go to cities for education, learning of trade and in search of white-collar jobs. This finding corroborates the expression of Kehinde et al. (2018). Most of the cocoa-producing household heads (95.8\%) are married. This implies that cocoa production attracts more married people. This may be advantageous because more family labour would be available for farm work. Majority of the cocoa-producing household heads (68.4\%) are formally educated; hence, literate farmers were involved in cocoa production. This is a good indicator to the farmers' ability to comprehend and probably adopt new input that could improve their production. The result is in line with of Kehinde and Adeyemo (2017) and Adeyemo et al. (2020). The mean household size is about six persons. This implies that family labour in the famers' household would be readily available for cocoa production. This agrees with the findings of Kehinde et al. (2018). The mean

Table 2. Socio-economic characteristics of cocoa-producing households

\begin{tabular}{lc}
\hline Variables & $\begin{array}{c}\text { cocoa-producing } \\
\text { households }\end{array}$ \\
\hline Gender (\%) & 94.2 \\
Male & 5.8 \\
Female & $58.7( \pm 12.4)$ \\
Age (years) & 95.8 \\
Married (\%) & $6.4( \pm 3.22)$ \\
Household size (\#) & 68.3 \\
Formal education (\%) & $25( \pm 13)$ \\
\hline Years of farming experience & $5.7( \pm 3.68)$ \\
Farm size (ha) & 8 \\
\hline Extension Agent (\%) &
\end{tabular}

Source: Field survey, 2020; Data in brackets () represent the standard deviation 


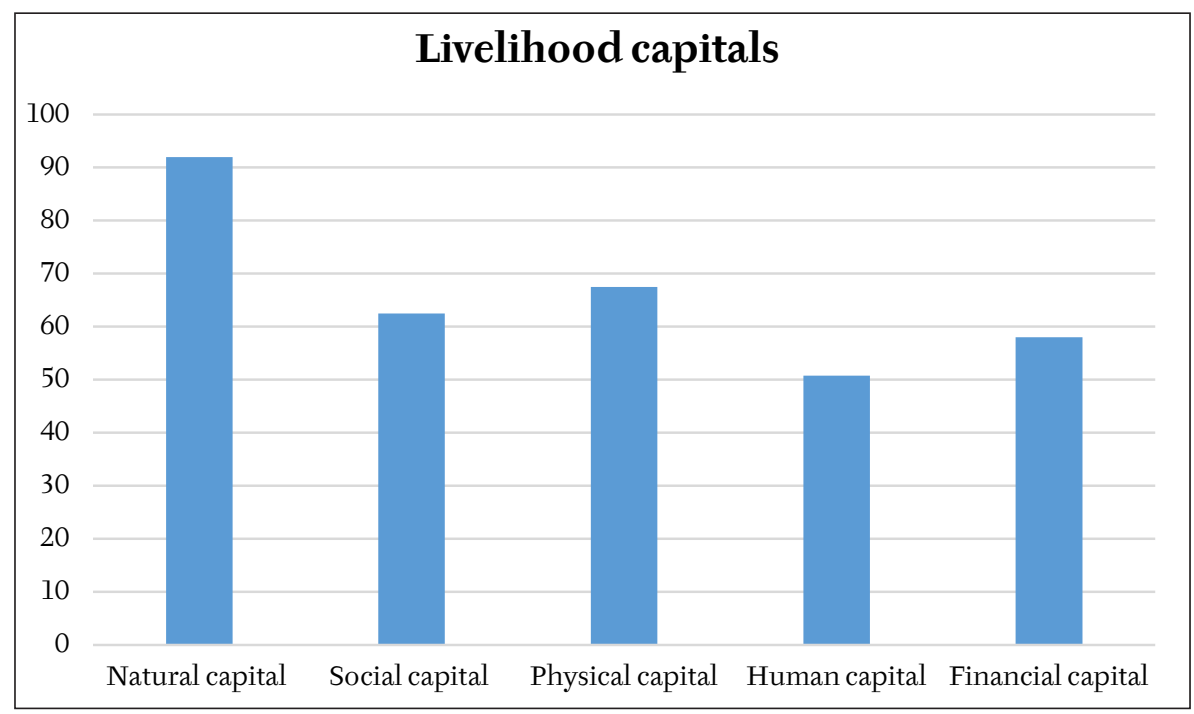

Figure 2. Livelihood capitals available to cocoa-producing households. Source: Field survey, 2020

years of farming experience is 25 years, indicating that the farmers have been in cocoa farming for quite a long time and they have many years of cocoa farming experience. This is in line with the findings of Kehinde and Adeyemo (2017), and Adeyemo et al. (2020). Access to extension services remains a challenge as just $8 \%$ of cocoa-producing households were visited by extension agents in the last production season. This implies that cocoa-producing households may not be exposed to much information on EU approved pesticides. The mean farm size is 5.7 ha. This implies that the farmers are small-scale farmers. This result is supported by Adeogun (2008).

\section{Cocoa-producing households' access to livelihood capitals}

Cocoa-producing households' access to livelihood capitals is presented in Figure 2. Majority of cocoa-producing households (92\%) have access to natural capital, followed by physical capital (67.5\%), social capital (62.5\%), financial capital (58\%), whereas only a few (50.8\%) have access to human capital. The result implies that though cocoa-producing households have fair access to all the five categories of livelihood capitals in varying percentages, natural capital is the most accessible livelihood capital by cocoa-producing households. This could be attributed to socio-cultural setting and the communal system of African rural communities that give every member of rural household privilege to own or use a land for farming activities. The result agrees with the findings of Allison and Horemans (2006), Ahmed et al. (2008), and Serrat (2017). However, cocoa-producing households had lower access to human capital. This could be attributed to the circumstance that literate and skilled people in rural Africa communities prefer to go to

Table 3. Factors affecting cocoa-producing households' access to livelihood capitals

\begin{tabular}{lccccc}
\hline Variables & $\begin{array}{c}\text { Physical Capital } \\
\text { Coeff. (Z) }\end{array}$ & $\begin{array}{c}\text { Natural Capital } \\
\text { Coeff. (Z) }\end{array}$ & $\begin{array}{c}\text { FinancialCapital } \\
\text { Coeff. (Z) }\end{array}$ & $\begin{array}{c}\text { Human Capital } \\
\text { Coeff. (Z) }\end{array}$ & $\begin{array}{c}\text { Social Capital } \\
\text { Coeff. (Z) }\end{array}$ \\
\hline Constant & $0.971^{* *}(2.49)$ & $0.315^{* *}(2.19)$ & $2.84^{* *}(2.52)$ & $0.625^{* * *(3.57)}$ & $0.491^{* *}(2.51)$ \\
GENDER & $1.569(1.13)$ & $1.307^{* *}(2.01)$ & $2.446^{* *}(1.96)$ & $0.428^{* *(2.47)}$ & $1.227(0.36)$ \\
AGE & $0.082^{* *}(2.11)$ & $0.021(0.69)$ & $0.033(1.03)$ & $0.173(0.87)$ & $0.118(0.61)$ \\
H/H EDU & $-0.069(-1.24)$ & $-0.055(-1.23)$ & $0.025(0.51)$ & $1.625^{* * *(5.70)}$ & $2.102^{* * *(2.61)}$ \\
FARM SIZE & $0.094^{* *}(2.25)$ & $-0.011(-0.37)$ & $0.615^{* * *}(3.31)$ & $0.493(0.04)$ & $0.050(0.02)$ \\
FARMEXP & $-0.017(-0.51)$ & $0.035^{* * *(3.22)}$ & $-0.005(-0.17)$ & $1.870^{* * *(3.47)}$ & $0.186(1.09)$ \\
H/H SIZE & $-0.027^{* *}(-2.31)$ & $-0.074(-0.93)$ & $-0.147(-1.59)$ & $0.652 * * *(4.07)$ & $0.472 * * *(3.24)$ \\
MEMB ASS & $0.130^{* * *}(4.21)$ & $1.729 * * *(3.01)$ & $1.716^{* * *}(2.74)$ & $0.480(0.92)$ & $0.290(0.17)$ \\
INCOMLEV & $-0.347(-1.28)$ & $-0.148(-0.73)$ & $0.040(0.18)$ & $0.493(0.14)$ & $0.159(0.07)$ \\
\hline
\end{tabular}

Source: Field Survey, 2020

Note: Significance of coefficient at 10\% $=*, 5 \%=* *$ and $1 \%=* * * \mathrm{chi}^{2}(10)=151.1 ;$ Prob $>\mathrm{Chi}^{2}=0.000$ 
cities in search of lucrative white-collar jobs, where they could receive a better pay rather than making their skilled labour available for farming activities. The result agrees with the findings of Peng et al. (2017).

\section{Factors affecting cocoa-producing households' access to livelihood capitals}

The likelihood ratio test $\left(\chi^{2}(10)=151.11 ; p>0.000\right)$ of the model reveals that the entire model is of good fit (Table 3). Age, farm size, household size and membership of cooperative societies significantly influence households' access to physical capital. The coefficients of age, farm size and membership in cooperative societies had a positive and significant influence on the households' access to physical capital. The plausible reason for the positive relationship between age and access to physical capital is that the old household heads invest in physical asset for security reasons. Rents on physical asset would generate income for the households when the household heads get older and their energy begin to depreciate. This report is in accordance with findings of Akerele and Oyebanjo (2016), and Oyedepo et al. (2016). Farm size has a positive effect on access to physical capital. The reason could be that large farms allow diversification of enterprise and thus, improves investment in physical asset. Also, large farms with formal title would enable household head to have access to inputs and credit which could improve investment in physical asset. This result is in line with the findings of Akerele and Oyebanjo (2016) and Oyedepo et al. (2016). Membership in cooperative societies has a positive effect on access to physical capital. The reason could not be unconnected to the numerous benefits, a cooperative society offers to its members which enhance the economic and social status of members. This finding is also supported by those of Obisesan (2013), and Igbalajobi et al. (2013), whereas the coefficient of household size has a negative and significant influence on the probability of households' access to physical capital. This implies that small households have access to physical capital. This might be connected to the circumstance that consumption pressure of large household may deprive household head the opportunity to invest in physical assets. This is supported by the reports of Olorunsanya and Omotesho (2012), Omotosho et al. (2017) and Olasimbo and Oladokun (2020).

Gender, farming experience and membership in cooperative societies significantly influenced households' access to natural capital. The coefficients of gender, farming experience, membership in cooperative societies has a positive and significant influence on the households' access to natural capital.
The positive relationship between gender and access to natural capital could be connected to the communal land ownership system existing in Africa rural village which favours men to have easy access to natural asset such as land than women. This result is in line with Deininger et al. (2014) and Onya et al. (2019). Farming experience has a positive effect on access to natural capital. The reason is that an experienced household head has understanding of the planning and decision-making skills which improves their access to natural capital. This is also noted by Tesso et al. (2012). Also, membership in cooperative societies has a positive effect on access to natural capital. This is linked to the roles of co-operatives to enhance the socio-economic status of their members and as such may assist their members to acquire and access natural assets.

Gender, farm size and membership in cooperative societies significantly influenced households' access to financial capital. The coefficients of gender, farm size and membership in a cooperative society have a positive and significant influence on the households' access to financial capital. Gender has positive effect on households' access to financial capital. This is connected to the customs and social norms operating in African countries which restrict women's control and ownership of economic asset. As a matter of fact, African women engage in non-economic activities such as child care, cooking, cleaning, fetching fire woods that does not generate income stream. This affirms the findings of Auma and Mensah (2014). The possible reason for a positive relationship between farm size and access to financial is that large farms increase investment options and scale of operation which could increase the revenue of the household. Also, a large farm is an important asset that could serve as collateral to accessing formal credit. This result is consistent with the report of Awunyo-Vitor and Abankw (2012), and Owuso (2017). Also, membership in cooperative societies has a positive effect on access to financial capital. This is linked to the financial services render by cooperative societies to their members with the objective of improving their socio-economic status. This result is consistent with the report of Owuso (2017) and Silong (2017).

Gender, years of education, farming experience and household size significantly influenced households' access to human capital. The coefficient of gender, years of education, farming experience and household size have a positive and significant influence on the households' access to human capital. Gender has a positive effect on access to human capital. The reason 
is that the male household heads provide the basic needs of the household. Therefore, they may employ skill labour to improve their income. Years of education have positive effect on access to human capital. The reason is that education empowers farmers with required knowledge and skills to increasing their productivity. Consequently, they may employ skill labour to improve cocoa productivity. This result contradicts the finding of Glauben et al. (2008) and Faridi and Basit (2011). Similarly, years of farming experience have a positive effect on access to human capital. The probable reason is that years of experience help farmers to make sound decisions on the management of their farms. Also, household size has a positive effect on access to human capital. The probable reason is that farming household could obtain skilled labour from family sources for their various farm activities.

Years of education and household size significantly influenced households' access to social capital. The coefficient of years of education and household size have a positive and significant influence on the households' access to social capital. Years of education has positive effect on access to social capital. The implication of this is that education motivates farmers to seek for information, knowledge and skills to improve their managerial abilities. This result is in line with the findings of Mikiewicz et al. (2011) and Ochago et al. (2017). The plausible reason for positive relationship between household size and access to social capital is that the consumption needs of large households pressurize the household head to join social groups to take advantage of social capital to improve their farming activities. This result is in line with the findings of Davis et al. (2012) and Temesgen et al. (2015).

\section{Cocoa-producing households' probability and intensity of adoption of the EU approved Pesticides}

\section{Probability of adoption of the EU approved pesticides}

Majority of cocoa-producing households (81\%) adopt approved pesticides. This result indicates that majority of the cocoa-producing households are aware of the EU pronouncement on cocoa pesticides and they are using approved pesticides. It must be, however, stated that some of the farmers using the approved pesticide still combined the banned pesticides with the approved ones as indicated by the farmers during the survey. The farmers indicated that banned pesticides are cheap and readily available in local markets. In addition, many farmers still do not understand the rationale behind
Table 4. Intensity of adoption of the EU approved pesticides

\begin{tabular}{lc}
\hline Intensity of adoption per hectare & Percentage \\
\hline $50 \mathrm{~g}$ to 5 litres & 75.0 \\
5 litres to 10 litres & 17.5 \\
10 litres to 15 litres & 6.76 \\
15 litres to 20 litres & 0.74 \\
Total & $\mathbf{1 0 0}$ \\
\hline
\end{tabular}

Source: Field Survey, 2020

banning of some pesticides by the Federal Government, as they think it is purely a political strategy against pesticide marketers. This result is in line with the findings of Tijani (2006), Mokwunye et al. (2012), and Mokwunye et al. (2014).

\section{Intensity of adoption of the EU approved pesticides}

The intensity of adoption of the EU approved pesticides is presented in Table 4. In the study, the adoption intensity of the EU approved pesticides was defined as the quantity of approved pesticide used by the respondents per hectare on their cocoa farms. Most of cocoa-producing households (75\%) use $50 \mathrm{~g}$ to 5 litres of approved pesticides per hectare on their cocoa farms. This implies that majority of the farmers applied dose below the recommended rate. A few (0.74\%) used 15 to 20 litres of approved pesticides per hectare on their cocoa farms. This finding revealed that adoption intensity of EU approved pesticides is still relatively low and have not made enough headway. The result further affirms the earlier position that the farmers still combine banned pesticides with the approved ones. As indicated by the farmers, the approved pesticides are too expensive and scarce. For this reason, the farmers cannot afford to use only approved pesticides on their cocoa farms. This agrees with the study of Adefila (2013).

\section{Effect of access to livelihood capitals on adoption and intensity of EU approved pesticides among cocoa-producing households}

The double hurdle regression results of EU approved pesticides are presented in Table 5. The first hurdle showed the factors that influence the decision to adopt EU approved pesticides using Probit regression model, while the second hurdle showed factors that influence adoption intensity using Truncated regression model. The first hurdle (Probit regression) result shows that amongst the socio-economic characteristics of the households that were included in the model, gender, education and membership in a cooperative society significantly influence the probability of the household to adopt EU approved pesticides. The possible reason for a positive relationship 
between gender and adoption of EU approved is that male-headed households have access to information on improved technologies through freedom of mobility and participation in different meetings and trainings, as influenced by socio-cultural norms and traditions prevailing in African countries. Also due to the prevailing traditions, male farmers have freedom to participate in many income-generating activities. This provides the male farmers with the wealth to easily afford new technologies. This result is in line with those of Tefera et al. (2016), and Melesse (2018). Education has a positive effect on the adoption of EU approved pesticide. The reason is that education enhances farmers' ability to gain, understand and construe information on new technology. The result agrees with data of Shiferaw et al. (2009; 2014). Also, membership in cooperative societies has a positive effect on the adoption of EU approved pesticides. It is traced to the roles of cooperative in improving the managerial ability of farmers. Cooperative allows interaction and cross-fertilisation of ideas on improved technologies among farmers, as also stated by Onyeneke (2017) and Danso-Abbeam et al. (2017).

Interestingly, the result also reveals that access to livelihood capital variables is significant in determining the adoption of EU approved pesticides (Table 5). Access to human capital, physical capital and financial capital has a positive and significant influence on the probability of adopting EU approved pesticides. The plausible reason is that the engagement of skill labour in active farm work force encourages farmers to adopt new labour using technologies such as improved varieties of seeds, fertilisers and pesticides. This is in line with findings of Tefera et al. (2016), Danso-Abbeam et al. (2017) and Melesse (2018). Access to physical asset also has positive effect on adoption of EU pesticides. It must be noted that, having access to physical capital is an indicator of high socio-economic status, especially in African countries and as such, physical capital could drive agricultural technology adoption. The implication of this is that cocoa-producing households with better access to physical capital would be able

Table 5. Effect of access to livelihood capitals on adoption and intensity of EU approved pesticide among cocoa producing households

\begin{tabular}{|c|c|c|c|c|c|c|}
\hline \multirow{2}{*}{ Variables } & \multicolumn{3}{|c|}{ First Hurdle (Probit) } & \multicolumn{3}{|c|}{ Second Hurdle (Truncated) } \\
\hline & Coeff. & Standard Error & $\mathbf{Z}$ & Coeff. & Standard Error & $\mathbf{Z}$ \\
\hline Const. & $5.507^{* * *}$ & 4.066 & 3.35 & $4.344 * * *$ & 2.943 & 3.48 \\
\hline Gender & $0.099 * * *$ & 0.057 & 2.75 & $0.075^{*}$ & 0.046 & 1.64 \\
\hline Age & 1.485 & 3.409 & 0.44 & 0.346 & 2.324 & 0.15 \\
\hline Marital status & 1.083 & 0.579 & 1.87 & 0.864 & 0.508 & 1.70 \\
\hline Education & $0.361^{* *}$ & 0.629 & 2.54 & 0.079 & 0.419 & 0.19 \\
\hline Farm size & 0.011 & 0.065 & 0.17 & $0.019^{* * *}$ & 0.046 & 4.42 \\
\hline Farming experience & 0.564 & 0.753 & 0.75 & 0.089 & 0.070 & 1.28 \\
\hline Household size & 0.080 & 0.187 & 0.43 & $-0.091^{* * *}$ & 0.144 & -3.63 \\
\hline Association & $2.784 * * *$ & 1.594 & 3.75 & $2.191^{* * *}$ & 1.178 & 3.86 \\
\hline Income & 0.296 & 0.493 & 0.60 & 0.186 & 0.353 & 0.53 \\
\hline Access to extension & 1.308 & 1.59 & 1.13 & 0.607 & 0.785 & 0.77 \\
\hline Human capital & $0.199 * * *$ & 0.668 & 3.30 & $0.040^{* *}$ & 0.488 & 2.08 \\
\hline Physical capital & $0.986^{* *}$ & 0.789 & 2.25 & $0.339 * * *$ & 0.512 & 2.66 \\
\hline Natural capital & 0.115 & 0.145 & 0.79 & 0.436 & 0.273 & 1.60 \\
\hline Financial capital & $0.907^{* * *}$ & 0.595 & 2.53 & 0.184 & 0.237 & 0.78 \\
\hline Social capital & 0.410 & 0.579 & 0.71 & $0.375^{* * *}$ & 0.414 & 2.91 \\
\hline No. of Obs. & 120 & & & 120 & & \\
\hline LR Chi 2 (18) & 43.83 & & & 36.73 & & \\
\hline Log likelihood & -20.053 & & & -27.599 & & \\
\hline Prob $>$ Chi & 0.001 & & & 0.004 & & \\
\hline
\end{tabular}

Source: Field Survey, 2020 Note: Significance of coefficient at $5 \%=* *$ and $1 \%=* * *$ 
to afford expensive technologies. This is in line with Abdoulaye et al. (2018). The possible reason for a positive relationship between access to financial capital and adoption of EU pesticides is that access to financial capital offers opportunity to invest in productivity enhancing technologies such as improved seed, fertilisers and pesticides. This result confirms the findings by Ngombe et al. (2014) and Wollni and Andersson (2014).

In the second hurdle, socio-economic characteristics such as gender, farm size, household size, membership in cooperative society and access to livelihood capital variables such as human capital, physical capital and social capital are significant in determining the intensity of EU approved pesticides (Table 5). The coefficient of gender, farm size, and membership in cooperative society are positive and significant with respect to intensity of adopting of EU approved pesticides. The possible reason for positive relationship between gender and adoption intensity of EU approved pesticides is that male-headed households have access to information on the benefit of intensifying improved technologies through participation in different trainings, as predisposed by socio-cultural traditions prevailing in African countries. This result is in line with the findings of Tefera et al. (2016) and Melesse (2018). The plausible reason for a positive relationship between farm size and adoption intensity of EU approved pesticides is that large farm allows diversification of enterprises and as such, large farms generates more income than small size. Therefore, cocoa-producing households with large farms are wealthy enough and have enough farm lands to intensify technology adoption. This finding confirms to the studies by Lavison (2013) and Singh et al. (2014). Also, membership of cooperative societies has positive effect on the adoption intensity of EU approved pesticide. It is traced to the roles of cooperative in improving the managerial ability of farmers by allowing cross-fertilisation of ideas on the importance and application of improved technologies among its members. The result agrees with Onyeneke (2017) and Danso-Abbeam et al. (2017). On the contrary, the coefficient of household size had a negative significant with respect to intensity of adopting of EU approved pesticides. This implies that small cocoa-producing households are likely to intensify the adoption of EU approved pesticides. The negative relationship of the variable with adoption could be linked to the increasing consumption pressure associable with a large family negatively affects adoption decision. This result corroborates the findings of Ouma et al. (2002), and Bekele and Drake (2003).
Fascinatingly, access to livelihood capitals such as human, physical and social capitals are significant in determining the intensity of EU approved pesticides. Access to human capital has positive effect on intensity of adoption of EU approved pesticide. The reason is that engagement of skill labour in active farm work force encourages farmers to intensify labour using technologies such as improved varieties of seeds, fertiliser and pesticides. This is in line with findings of Tefera et al. (2016), Danso-Abbeam et al. (2017) and Melesse (2018). Access to physical asset also has positive effect on intensity of adoption of EU pesticides. Having access to physical capital is an indicator of high socio-economic position especially in African countries and as such, cocoa-producing households with better access to physical capital could afford expensive technologies. This is in line with findings of Abdoulaye et al. (2018). Social capital has positive relationship with the technology adoption. Social groups engage their members in social learning about new technology which is likely to foster adopting new technologies among their members. This mirrored previous findings by Katungi and Akankwasa (2010) and Adepoju and Oni (2012).

\section{CONCLUSION AND RECOMMENDATIONS}

This study revealed that majority of the cocoa-producing households (92\%) have access to natural capital, followed by physical capital (67.5\%), social capital (62.5\%), financial capital (58\%), while, only a few (50.8\%) have access to human capital. Age, farm size, membership of cooperative society, gender, year of education and farming experience significantly influenced cocoa-producing households' access to livelihood capitals positively. Majority of the respondents (81\%) adopt approved pesticides. The first hurdle (Probit regression) result showed that gender, marital status, membership of cooperative society and access to livelihood capital variables such as human, physical and financial capitals significantly and positively influence the cocoa-producing households to adopt EU approved pesticides. In the second hurdle, gender, marital status, farm size, household size, membership in farmers' association and access to livelihood capital variables such as human capital, physical capital and social capital are significant in determining the intensity of EU approved pesticides. The study concluded that access to livelihood capitals has potentials of hastening adoption of EU approved pesticides. Other factors include gender, education, farm size and membership in cooperative society. Therefore, this study suggests that government policy 
on uptake of EU approved pesticides should pay more attention on cocoa-producing households' access to livelihood capital, gender, education, farm size and membership in cooperative society. Most importantly, policy package to encourage access to livelihood capitals must be strongly advocated.

\section{CONFLICT OF INTEREST}

The authors declared no conflicts of interest with respect to research, authorship and publication of this article.

\section{ETHICAL COMPLIANCE}

The authors have followed the ethical standards in conducting the research and preparing the manuscript.

\section{REFERENCES}

Abdoulaye T., Wossen T., Awotide B. (2018): Impacts of Improved Maize Varieties in Nigeria: Ex-Post Assessment of Productivity and Welfare Outcomes. Food Security 10: 369-379.

Abdullahi S. U. (2008): The Vice Chancellor's opening remarks delivered at the National Workshop on pesticide usage, handling and safety procedures held at NAERLS conference hall, Ahmadu Bello University, Zaria on 18th November.

Adefila J. O. (2013): Spatial effects of cocoa production on rural economy in Idanre - Ifedore area, Ondo state of Nigeria. Asian Journal of Agriculture and Rural Development 3: 56-66.

Adeogun S. O. (2008): Adoption of cocoa rehabilitation techniques among cocoa farmers in selected states of Nigeria. An unpublished PhD Thesis in the Department of Agricultural Extension and Rural Development, University of Ibadan, Ibadan Nigeria. $86 \mathrm{p}$.

Adepoju A. A., Oni A. O. (2012): Investigating endogeneity effects of social capital on household welfare in Nigeria: a control function approach. Quarterly Journal of International Agriculture 51: 73-96.

Adeyemo R., Kehinde A. D., Oyenpemi L. O. (2020): Assessing Resource Use Efficiency and Investment in Cocoa Enterprise: A Case of Osun State Nigeria. Agricultura 113-114: 260-269.

Afrane G., Ntiamoah A. (2011): Use of pesticides in the cocoa industry and their impact on the environment and the food chain. In Stoytcheva DM (Ed.) Pesticides in the modern world-risks and benefits. InTech: 51-68. http://www.intechopen. com/books/pesticides-in-the-modern-world- risks-and-benefits/ use-of-pesticides-in-thecocoaindustry-and-their-impact-on-the-environmentand-the-food-chain.

Ahmed N., Allison E. H., Muir J. F. (2008): Using the sustainable livelihoods framework to identify constraints and opportunities to the development of freshwater prawn farming in southwest Bangladesh. Journal of the World Aquaculture Society 39: 598-611.

Akerele E. O., Oyebanjo O. (2016): Analysis of Asset ownership and labour inputs among farming households in ilaro agricultural zone, Ogun State. Journal of Research on Humanities and Social Sciences 6: 1-8.

Allison E. H., Horemans B. (2006): Putting the principles of the sustainable livelihoods approach into fisheries development policy and practice. Marine Policy 30: 757-766.

Amao O. D., Oni O., Adeoye I. (2015): Competitiveness of cocoa-based farming household in Nigeria. Journal of Development and Agricultural Economics 7: 80-84.

Auma D., Mensah P. (2014): Determinants of access to credit and demand among small-holder farmers in Tigray region, Ethiopia. Master Thesis, Norwegian University of Life Sciences, School of Economics and Business, Oslo, Norway.

Awunyo-Vitor D., Abankwa V. (2012): Substitutes or compliments? Formal and informal credit demand by maize farmers in Ashanti and Brong Ahafo Regions of Ghana. International Journal of Agriculture and Forestry 2: 105-112.

Bateman R. (2010): Pesticide use in Cocoa. A guide for training administrative and research staff. $2^{\text {nd }}$ Edition. International Cocoa Organization (ICCO), London. $70 \mathrm{p}$.

Bekele W., Drake L. (2003): Soil and water conservation decision behavior of subsistence farmers in the Eastern Highlands of Ethiopia: A case study of the Hunde-Lafto area. Ecological Economics 46: 437-451.

Bonabana-Wabbi J. (2002): Assessing factors affecting adoption of agricultural technologies: The case of Integrated Pest Management (IPM) in Kumi District, Eastern Uganda (Doctoral dissertation, Virginia Tech).

Cocco P., Satta G., Dubois S., Pili C., Pilleri M., Zucca M., Martine't Mannetje A., Becker N., Benavente, Y., de Sanjosé S., Foretova L., Staines A., Maynadié M., Nieters A., Brennan P., Miligi L., Ennas M. G., Boffetta P. (2013): Lymphoma risk and occupational exposure to pesticides: results of the Epilymph study. 
Occupational and Environmental Medicine 70: 91-98.

Cocoa Research Institute of Nigeria, CRIN (2015): List of pesticides currently approved for use on cocoa farms in Nigeria by the Cocoa Research Institute of Nigeria. https://crin.gov.ng/index.php/services/2uncategorised/90-approved-pesticides

Cragg J. G. (1971): Some Statistical Models for Limited Dependent Variables with Application to the Demand for Durable Goods. Econometrica 39: 82-844.

Danso-Abbeam G., Bosiako J. A., Ehiakpor D. S., Mabe F. N. (2017): Adoption of improved maize variety among farm households in the northern region of Ghana. Cogent Economics \& Finance 5: 1416896.

Davis K., Nkonya E., Kato E., Mekonnen D. A., Odendo M., Miiro R., Nkuba J. (2012): Impact of farmer field schools on agricultural productivity and poverty in East Africa. World Development 40: 402-413.

Deininger K., Hilhorst T., Songwe V. (2014): Identifying and addressing land governance constraints to support intensification and land market operation: evidence from 10 African countries. Food Policy 48: 76-87.

Diniz F. H., Hoogstra-Klein M. A., Kok K., Arts B. (2013): Livelihood strategies in settlement projects in the Brazilian Amazon: determining drivers and factors within the Agrarian Reform Program. Journal of Rural Studies 32: 196-207.

Fang Y., Fan J., Shen M., Song M. (2012): Gradient effect on farmers' income in the mountain areas and its implication for poverty alleviation strategies: empirical analysis from the upper reach of Minjiang River. Journal of Material Science 9: 869-878.

Fang Y., Qin D., Ding Y. (2011): Frozen soil change and adaptation of animal husbandry: a case of the source regions of Yangtze and Yellow Rivers. Environment Science Policy 14: 555-568.

Faridi M. Z., Basit A. B. (2011): Factors Determining Rural Labour Supply: A Micro Analysis. Pakistan Economic and Social Review 49: 91-108.

Gill H. K., Garg H. (2014): Pesticides: environmental impacts and management strategies. In: Soloneski S (Ed.) Pesticides-toxic aspects. InTech: 188-230.

Glauben T., Herzfeld T., Wang X. (2008): Labour Market Participation of Chinese Agricultural Household: Empirical Evidence from Zhejiang Province. Food Policy 33: 32-340.

Igbalajobi O., Fatuase A. I., Ajibefun I. (2013): Determinants of Poverty Incidence among Rural Farmers in Ondo State, Nigeria. American Journal of Rural Development 15: 13-137.
International Cocoa Organization, ICCO (2008): Manual on pesticides use in cocoa. ICCO Press releases of 10 June 2008 by ICCO Executive Director Dr. Jan Vingerhoets. International Cocoa Organization (ICCO), London. Available online at http://www.icco. org/about/press2.aspx?Id=v3110299.

Katungi E., Akankwasa K. (2010): Community-Based Organizations and Their Effect on the Adoption of Agricultural Technologies in Uganda: A Study of Banana (Musa spp.) Pest Management Technology, AGRIS, Food and Agriculture Organization of the United Nation.

Kehinde A. D., Adeyemo R. (2017): A Probit Analysis of Factors Affecting Improved Technologies Dis-adoption in Cocoa-Based Farming Systems of Southwestern Nigeria. International Journal of Agricultural Economics 2: 35-41.

Kehinde A. D., Adeyemo R., Oke J. T. O., Ogunleye A. S. (2018): Effects of access to credit and membership in farmers' cooperatives on improved technologies adoption categories in cocoa-based farming systems of Southwestern Nigeria. International Journal of Cooperatives Studies 7: 22-29.

Lavison R. (2013): Factors Influencing the Adoption of Organic Fertilizers in Vegetable Production in Accra, MSc. Thesis, Accra, Ghana.

Melesse B. (2018): A Review on Factors Affecting Adoption of Agricultural New Technologies in Ethiopia. Journal Agricultural Science and Food Research 9: 1-4.

Mikiewicz P., Jonasson J. T., Gudmundsson G., Blondal K. S., Korczewska D. M. (2011): Social capital and education: Comparative research between Poland and Iceland. (Ed.) Mikiewicz, P. Available at http:// www.dsw.edu.pl/fileadmin/user_upload/Upload/ Social_Capital_and_education._Comprarative_ research_between_Poland_and_Iceland.pdf. Retrieved August 27, 2020.

Mokwunye I. U., Babalola F. D., Asogwa U. E., Idris N., Aderolu I. A., Mokwunye F. C., Idrisu M. (2014): Compliance of agrochemical marketers with banned cocoa pesticides in Southwest Nigeria. Journal of Agricultural Sciences 59: 161-174.

Mokwunye I. U., Babalola F. D., Ndagi I., Idrisu M., Mokwunye F. C., Asogwa E. U. (2012): Farmers' compliance with the use of approved cocoa pesticides in cocoa producing states of Nigeria. Journal of Agriculture and Social Research 12: 44-60. Mustapha S. B., Undiandeye U. C., Sanusi A. M., Bakari. S. (2012): Analysis of adoption of improved rice production technologies in Jeer local government 
area of Borno state, Nigeria. International Journal of Development and Sustainability 1: 1112-1120.

National Bureau of Statistics (NBS) (2017): National Bureau of Statistics Official Gazatte on Demography Statistics Bulletin. Retrieved from http://nigerianstat. gov.ng/elibrary.

National Population Census (NPC) (2007):National Bureau of Statistics Official Gazatte (FGP71/52007/2,500(OL24)Abuja,2007 URLhttp:// www.nigerianstat.gov.ng

National Population Commission (NPC) (2007): Population Figure. Federal Republic of Nigeria, Abuja. Retrieved from http://www.npc.gov

Ngombe J., Kalinda T., Tembo G., Kuntashula E. (2014): Econometric Analysis of the Factors That Affect Adoption of Conservation Farming Practices by Smallholder Farmers in Zambia. Sustainable Development 7: 124-138.

Obisesan A. A. (2013): Credit Accessibility and Poverty among Smallholder Cassava Farming Households in South West Nigeria. Greener Journal of Agricultural Sciences 3: 121-129.

Ochago R., Mangheni M. N., Miiro R. F. (2017): Which socio-economic factors matter in farmer group participation? Evidence from coffee pest management learning groups in Mt Elgon region, Uganda. International Journal Agricultural Extension 5: 23-38.

Olasimbo Y., Oladokun M. (2020): Asset Ownership by Women in Urban and Rural South West Nigeria. Economics 9: 21-26.

Olorunsanya E. O., Omotesho O. A. (2012): A gender analysis of poverty among rural farming households in North Central Nigeria. European Journal of Social Sciences 28: 366-376.

Omotosho K., Adekunle C. P., Oyedepo E. O., Oladeji S. O., Dekanmbi A. A. (2017): Patterns and determinants of asset ownership among farm households in Odeda local government area of Ogun State, Nigeria. FUOYE Journal of Agriculture and Human Ecology 1: 23-34.

Onya S. C., Ugochukwu G. C., Ejiba I. V. (2019): Farm-level determinants of access to land by arable crop farmers in Ikwuano local government area of Abia state, Nigeria. Journal of Tropical Agriculture, Food, Environment and Extension 18: 50-55.

Onyeneke R. U. (2017): Determinants of adoption of improved technologies in rice production in Imo State, Nigeria. African Journal of Agricultural Research 12: 888-896.

Ouma J. O., Murithi F. M., Mwangi W., Verkuij H., Gethi M., De Groote H. (2002): Adoption of maize seed and fertilizer technologies in Embu district, Kenya: CIMMYT.

Owusu S. (2017): Factors Affecting Farm Households' Access to Credit in the Afigya-Kwabre District of Ghana. Scientific Research in Social Sciences \& Management Studies 2: 98-113.

Oyedepo E. O., Afolami C. A., Okuneye P. A., Sodiya C. I. (2016): Asset Ownership by rural Women and Poverty status of rural households in Ogun State, Nigeria. MOOR Journal, Institute of Agricultural Research Ibadan 16: 103-123.

Peng W., Zheng H., Robinson B. E., Li C., Wang F. (2017): Household Livelihood Strategy Choices, Impact Factors, and Environmental Consequences in Miyun Reservoir Watershed, China. Sustainability 9: 175.

Popoola O. A., Ogunsola G. O., Salman K. K. (2015): Technical Efficiency of Cocoa Production in Southwest Nigeria. International Journal of Agricultural and Food Research [IJAFR] 4: 1-14.

Rogers E. M. (2003): Diffusion of innovations. $5^{\text {th }}$ Edition, Free Press. New York, 576 p.

Serrat O. (2017): The Sustainable Livelihoods Approach. Chapter in Knowledge Solutions, Springer Link, pp. 21-26.

Shiferaw B., Kassie M., Jaleta M., Yirga C. (2014): Adoption of improved wheat varieties and impacts on household food security in Ethiopia. Food Policy 44: 272-284.

Shiferaw B. A., Okello J., Reddy R. V. (2009): Adoption and adaptation of natural resource management innovations in smallholder agriculture: reflections on key lessons and best practices. Environment, Development and Sustainability 11: 601-619.

Silong A. K. F. (2017): Credit and the Technical Efficiency of Sheep and Goat Production among Rural Female Farmers in Nasarawa State, Nigeria. Unpublished thesis Submitted in Fulfilment of the Requirements for the Degree of Doctor of Philosophy. The University of Reading Graduate Institute of International Development and Applied Economics (GIIDAE), School of Agriculture, Policy and Development.

Singh S. V., Singh P. K., Singh A. V., Sohal J. S., Kumar N., Chaubey K. K., Srivastava A. K. (2014): 'Bio-Load' and Bio-Type Profiles of Mycobacterium avium subspecies paratuberculosis Infection in the Domestic Livestock Population Endemic for Johne's Disease: A Survey of 28 years (1985-2013) in India. Transboundary and Emerging Diseases 61: 43-55.

Tefera T., Tesfay G., Elias E., Diro M., Koomen I. (2016): Drivers for adoption of agricultural technologies and 
practices in Ethiopia. CASCAPE Project Report No. NS_DfA_2016_1, Addis Ababa/Wageningen.

Temesgen D., Umer H., Jamal Y. (2015): Determinants of farm women participation in agricultural extension training programs: A case from selected district of Oromia Region of Ethiopia. International Journal of Agricultural Science Research 4: 067-077.

Tesso G., Emana B., Ketema M. (2012): Analysis of vulnerability and resilience to climate change induced shocks in North Shewa, Ethiopia. Agricultural Sciences 3: 871-888.

Tijani A. A. (2006): Pesticide Use Practices and Safety Issues: The Case of Cocoa Farmers in Ondo State, Nigeria. Journal of Human Ecology 19: 183-190.

UNDP (2010): Cocoa scoping paper. Green commodities facilities. United Nations Development Programm (UNDP), $24 \mathrm{p}$.

UNECA (2013): Nigeria: country case study. Economic report on Africa 2013. United Nations Economic Commission for Africa (UNECA). http://www. uneca.org/sites/default/files/uploadeddocuments/ era2013_casestudy_eng_nigeria.pdf

Uwagboe E. O., Obatolu B. O., Mokwunye I. U., Asogwa E. U. (2011): Cropping practices of cocoa farmers in Nigeria. International Journal of Science and Nature 1: 267-271.

Verter N., Becvarova V. (2014): Analysis of Some Drivers of Cocoa Export in Nigeria in the Era of Trade Liberalization. Agris On-Line Papers in Economics and Informatics 6: 208-218.

Williamson S. (2003): The dependency syndrome: Pesticide use by African smallholders. Pesticide Action Network (PAN), London.

Wollni M., Andersson C. (2014): Spatial patterns of organic agriculture adoption: Evidence from Honduras. Ecological Economics 97: 120-128.

Received: June 4, 2020

Accepted after revisions: March 2, 2021 